Universidad de Panamá

Instituto de Estudios Nacionales
ISNN 1810-5491

Cuadernos Nacionales

$\mathrm{N}^{\circ} 27,25-53$, julio-diciembre, 2020

\title{
Literatura, identidades y racismo: apuntes teóricos ${ }^{14}$
}

\author{
Silvia Elena Solano Rivera \\ Universidad de Costa Rica \\ silisori@gmail.com
}

\section{Resumen}

En este ensayo pongo de relieve la estrecha relación que existe entre el texto literario, las construcciones-representaciones de identidades de un contexto determinado y las prácticas de desigualdad, explotación y dominio como el racismo. Mi punto de partida es la concepción del texto literario como práctica sociocultural que materializa, trabaja, produce, moldea, elabora y reelabora identidades, así como las ideologías (imaginarios, representaciones mentales y sistemas de valores) y las prácticas sociales ligadas a estas. De este modo, el presente texto se organiza en el engarce de tres grandes ejes: literatura como práctica social e ideológica, identidades y racismo.

Palabras clave: sociocrítica, discurso, ideología, identidades y racismo.

\begin{abstract}
In this essay I highlight the close relationship that exists between the literary text, the constructions-representations of identities in a given context and the practices of inequality, exploitation and domination such as racism. My starting point is the conception of the literary text as a sociocultural practice that materializes, works, produces, molds, elaborates and reworks identities, as well as ideologies (imaginaries, mental representations and value systems) and the social practices linked to these. Thereby, the present text is organized in the connection of three main themes: literature as social and ideological practice, identities and racism.
\end{abstract}

Keywords: sociocritical, discourse, ideology, identities and racism. 
la literatura crea imágenes muy específicas de las personas, en las cuales el yo y el otro se combinan de un modo especial

$$
\text { Mijaíl Bajtín }
$$

\section{Literatura como práctica social e ideológica}

Desde una concepción sociocrítica, la literatura se entiende como una práctica social y cultural:

es una práctica social en tanto es el resultado de una serie de selecciones operadas por diversos filtros sociales, económicos y culturales en los proyectos que los escritores han llevado a la etapa de la escritura, $[. .$.$] la literatura se concibe como un proceso material de una vida social dada$ (Amoretti, 1992, p. 77).

De acuerdo con Cros, el texto literario es un texto social-cultural, una de las formas en que la cultura se manifiesta, pues siguiendo a Althusser indica: "la cultura no posee existencia ideal, solo existe a través de sus manifestaciones concretas", situando en primer lugar al "lenguaje y las diversas prácticas discursivas" (Cros, 1997, p. 10). Entender la literatura como manifestación sociocultural, implica a su vez, que es una manifestación ideológica: "la cultura es el dominio donde lo ideológico se manifiesta con mayor eficacia" (Cros, 1997, p. 9). Esto por cuanto “dondequiera que está presente un signo también lo está la ideología” (Voloshinov, 1992, p. 33.). "Dado que la práctica de escritura es una práctica social, todo texto materializa las diversas voces y contradicciones sociohistóricas y socioculturales de las formaciones sociales e ideológicas que la originan" (Ramírez, 2004, p. 249), es decir, materializa distintos discursos. Tal y como apunta Bajtín, el texto es polifónico, dialógico y multiestilístico. Es por eso que este ensayo resalta la necesidad de analizar las ideologías-discursos materializados en los textos, particularmente el racismo: quiénes lo producen, quiénes lo reproducen, cómo se construye ese discurso-ideología racista en el texto, cuál es la relación que tiene con el contexto y la articulación de la identidad en los personajes.

Para Cros, el texto literario "no remite directamente a la sociedad" (1986, p. 75), o al contexto. Entre el texto y el contexto, median los discursos: "existe entre la estructura social y la estructura textual una mediación esencialmente discursiva" (Cros, 1986, p. 75). La relación texto-contexto se lleva a cabo a través de las estructuras de mediación. La relación entre literatura y contexto social "se nos muestra en el texto a través de un conjunto de huellas semióticas concretas y perceptibles" (Cros, 1986a, p. 113), es decir, que dicha relación se da a 
través de las estructuras de mediación, siendo las principales: el intertexto y el interdiscurso. Ambas herederas de una concepción de la literatura como práctica social y discursiva que parte de los aportes de Mijaíl Bajtín ${ }^{15}$.

Desde Teoría y estética de la novela, a través de su noción de dialogismo (década de 1930), Bajtín plantea la intertextualidad: existe una relación necesaria entre un enunciado con otros enunciados. Bajtín señala que todo enunciado se convierte en el vehículo de un decir heterogéneo en el que se cruzan las voces, los discursos y los textos del ambiente en que se inserta el enunciador. Cuando el sujeto quiere nombrar una cosa, encuentra la resistencia de la palabra ajena dicha antes por otros sobre esa misma cosa, de modo que lo que se pretende decir sobre un objeto entra en contacto con lo que otros han dicho sobre él. Así lo explica Bajtín:

entre la palabra y el objeto, entre la palabra y el individuo que habla, existe el medio maleable, frecuentemente difícil de penetrar, de las demás palabras ajenas acerca del mismo objeto, sobre el mismo tema... toda palabra encuentra siempre un objeto hacia el que orientarse, condicionado ya, contestado, evaluado, envuelto en una bruma que lo enmascara, o por el contrario, inmerso en la luz de las palabras ajenas que se han dicho acerca de él. El objeto está rodeado o impregnado de ideas generales, de puntos de vista, de valoraciones y acentos ajenos. La palabra orientada hacia su objeto entra en ese medio agitado y tenso, desde el punto de vista dialógico, de las palabras, de las valoraciones y de los acentos ajenos; se entrelaza en complejas relaciones, se une a algunos, rechaza a otros, o se entrecruza con los demás; todo esto modela sustancialmente la palabra que puede sedimentarse en todos sus estratos semánticos, complicar la expresión, influenciar por completo su aspecto estilístico (1989, p. 94).

Bajtín pone de relieve que todo enunciado- texto tiene una capacidad de relacionarse con una red de múltiples enunciados, entre los cuales se establece un diálogo, dando como resultado una polifonía en el nivel discursivo: "la palabra vive en la frontera entre su propio contexto y el contexto ajeno" (1989, p. 101). De esa manera, siempre que se escribe o siempre que se habla nos vemos obligados a citar las palabras de los otros: "Toda conversación está llena de trasmisiones e interpretaciones de palabras ajenas. En tales conversaciones existe, a cada paso, una cita o una referencia a lo que ha dicho una determinada persona, un periódico, un libro" (1989, p. 155). Eso mismo sucede en el proceso de escritura: un texto remitirá a otro texto.

Cros, siguiendo a Bajtín, considera que todo texto está escrito con arreglo a otro texto: el texto nuevo reconstruye y redistribuye los elementos del antiguo en su tejido. Y además, para Cros, la intertextualidad implica que la historia y la sociedad sean consideradas como textos a semejanza de cualquier otra práctica semiótica (1997, p. 22). La intertextualidad, según Cros, puede verse como una estrategia que convierte al texto en una arena conflictiva donde se citan y

15. Bajtín concibe el lenguaje no como un sistema de categorías gramaticales abstractas, sino "como saturado ideológicamente, como una concepción del mundo" (89). 
resuenan todas las voces sociales que luchan por obtener una primacía o un reconocimiento simbólico.

Asimismo, Cros enriquece los planteamientos de Michel Riffaterre sobre la intertextualidad. Mientras que para Riffaterre la intertextualidad es un efecto de lectura, es decir, algo que debe ser detectado por el lector según su competencia de lectura (1997, p. 6), para Cros la intertextualidad es una práctica de escritura, es decir, es el escritor quien a la hora de escribir ha dejado las huellas o las marcas de los otros textos con los que está dialogando. Así las cosas, conviene complementar ambas perspectivas, tal y como lo plantea Ramírez Caro: la intertextualidad "no es sólo como una estrategia de escritura, sino también como una estrategia de lectura", ya que "es un fenómeno que orienta la lectura del texto, dirige eventualmente la interpretación y sustituye la lectura lineal por una lectura estereométrica que nos permite comprender un texto por y con otro texto, un sentido por y con otro sentido" (Ramírez, 2000, p. 148).

Con respecto a la interdiscursividad, Cros indica, y en esto coincide con Van Dijk, que un discurso es una práctica social, pues "establece relaciones entre las instituciones sociales, procesos económicos y sociales, formas de comportamiento, sistemas de normas, técnicas, tipos de clasificaciones, modos de caracterización" (1986a, p. 58). Para Van Dijk, "el discurso es un fenómeno práctico, social y cultural", pues "los usuarios del lenguaje que emplean el discurso realizan actos sociales y participan en la interacción social, que a su vez está enclavada en diversos contextos sociales y culturales" (2000, p. 21). El interdiscurso "materializa a la vez estructuras mentales y las formaciones ideológicas producidas por una formación social" y, por ende, "traduce en operaciones semióticas, a través de múltiples trazados ideológicos, las contradicciones sociohistóricas en las que se halla inmerso el locutor" (Cros, 1986a, p. 116).

Así las cosas, como indica Ramírez Caro, la interdiscursividad debe entenderse como "la manifestación heteroglósica o polifónica de los textos o como la expresión de la ideología y la formación discursiva de las formaciones sociales por las que atraviesa el texto" (2000, p. 137). En arreglo a esta noción de interdiscursividad, "no es posible concebir discursos que funcionen de manera autónoma, pues estos se constituyen en relación con otros", "manteniendo entre sí relaciones múltiples y dialógicas" (2000, p. 146).

Desde Van Dijk y los Estudios Críticos del Discurso (ECD), el estudio del discurso adquiere relevancia en la medida en que este "juega un rol fundamental en la (re)producción de la dominación en las relaciones inter-grupales, en la sociedad, la política y la cultura” (2010, p. 67). El discurso tiene un papel central en "la reproducción de actitudes e ideologías racistas que son la base socio-cognitiva del sistema social del racismo" (2010, p. 68), pues "la socialización 
ideológica tiene lugar principalmente por medio del discurso" (1999, p. 245), ya que este "tiene una función especial en la expresión, implementación y, especialmente, en la reproducción de las ideologías, puesto que es sólo por medio del uso de la lengua, el discurso o la comunicación (u otras prácticas semióticas) que ellas pueden formularse explícitamente" (1999, p. 395).

La relevancia del discurso se debe a que "puede ser tanto una práctica racista discriminatoria por sí misma como, por otro lado, la fuente y el medio primario para la adquisición de prejuicios e ideologías racistas" (2010, p. 68). Es decir, el discurso racista puede ser tanto fruto de las ideologías racistas que "controlan las actitudes negativas específicas (prejuicios) acerca de los Otros", producto de "modelos mentales negativos que controlan todas las acciones, interacciones y discursos, y por lo tanto también las prácticas sociales", como semilla que "da lugar a modelos mentales sesgados que a su vez pueden ser actitudes e ideologías generalizadas, condensadas y racistas socialmente compartidas". Todo lo cual "cierra el círculo vicioso de la reproducción del racismo" y señala la necesidad de acceso al poder y de difusión pública de los discursos antirracistas para conseguir el cambio (2010, p. 69). Como puede verse, el texto literario está habitado por diversos discursos, lo cual implica que puede ser un vehículo más para la difusión de ideologías racistas o antirracistas que están ancladas en el contexto histórico, social y cultural del que el texto nace. De ahí la importancia de estudiar el texto literario y poder dar cuenta del contexto al que remite y en el que es producido. No debemos tomar el estudio de las estructuras de mediación como mera teoría que nos permite hacer gala de nuestra competencia lectora, sino visualizarlas críticamente de manera que podamos entender el texto literario como la práctica social, ideológica y cultural que es y no nos quedemos deslumbrados por su carácter estético.

Bien, si atendemos a la relación del texto con su contexto, veremos que así como los intertextos y los interdiscursos permiten establecer la relación entre el texto y su contexto, también lo hacen lo que Van Dijk llama cogniciones sociales, que comprenden los estereotipos y los prejuicios. Si para Cros la relación entre texto y contexto es mediada por los intertextos e interdiscursos, para Van Dijk las cogniciones median a su vez entre el discurso y la sociedad. Según Van Dijk, las cogniciones sociales constituyen una interfaz entre el discurso y la sociedad. Se trata de modelos, guiones o representaciones mentales que todos poseemos, es decir, encarnan "la combinación de representaciones mentales socialmente compartidas", mismas que conllevan una serie de actitudes y valores, todo lo cual conforma las ideologías (1999, p. 70). Para el tema que me ocupa, me centraré en los prejuicios y estereotipos, los cuales emergen en el discurso, ya sea de manera consciente o inconsciente (1999, p. 128), razón por la cual es la tarea de los ECD poner de manifiesto todas las cogniciones sociales, especialmente prejuicios y estereotipos en los que se fundamentan las ideologías de dominación. 
Debido a que "el discurso es como la proverbial punta del iceberg: la mayor parte de sus significados implícitos o presupuestos permanecen 'escondidos"” (1999, p. 50), es necesario evidenciar estereotipos y prejuicios, base de las ideologías de dominación, las cuales suelen manejarse discursivamente de manera solapada y sutil, para desmantelar dichas ideologías. Van Dijk sostiene que "las ideologías dominantes tenderán a ser implícitas y negadas, o consideradas como "naturales"”, mientras que "por definición, las ideologías de oposición tenderán a ser más explícitas y conscientes" (1999, p. 129), esto dada la maleabilidad del discurso, pues "no solo exhibe indirectamente ideologías, tal como pueden hacerlo también otras prácticas sociales, sino que también formula explícitamente creencias ideológicas de manera directa” (1999, p. 245).

Si entendemos el texto literario como práctica social y cultural, es fácil ver y comprender que en dicha práctica se materializan, trabajan, producen, moldean, elaboran y reelaboran identidades, las cuales son construidas discursivamente a través de la cultura, y por lo tanto también manifiestan ideologías. Así las cosas, conviene que como críticos literarios nos acerquemos más al concepto de identidades.

\section{Identidades}

De acuerdo con Larraín, Hall y Restrepo, las identidades se construyen a través del discurso y siempre en relación con el Otro: el estudio de las identidades deviene inevitablemente en el de las alteridades, pues constituyen "dos caras de la misma moneda" (Restrepo, 2012, p. 132) ${ }^{16}$. Tanto para Larraín como para Hall, "la identidad sólo puede construirse en la interacción simbólica con los otros". Se trata de "un proceso de construcción en el que los individuos se van definiendo a sí mismos en estrecha interacción simbólica con otras personas” (Larraín, 2003, p. 31). Las identidades "son más producto de la marcación de la diferencia y la exclusión que signo de una unidad idéntica y naturalmente construida", es decir, "las identidades se construyen a través de la diferencia, no al margen de ella" (Hall, 2003, p. 18. El destacado es mío), pues el yo solo puede construirse a través de su relación con el otro, con lo que no es. Hall sostiene, siguiendo a Laclau, que "la constitución de una identidad social es un acto de poder", puesto que

\footnotetext{
16. Autores como Hall, Larraín y Restrepo coinciden con lo planteado por Bajtín y Aínsa al señalar la imposibilidad de estudiar las identidades sin estudiar las alteridades. Señala Bajtín, "sólo al revelarme ante el otro, por medio del otro y con la ayuda del otro, tomo conciencia de mí mismo, me convierto en mí mismo. Los actos más importantes que constituyen la autoconciencia se determinan por la relación con la otra conciencia" (2000, p. 163). De modo similar, Aínsa sostiene que "solo de la imagen y de la contraimagen y de la confrontación de sus reflejos puede surgir una idea aproximada de la identidad" (1986, p. $31)$.
} 
si una objetividad logra afirmarse parcialmente, sólo lo hace reprimiendo lo que la amenaza. Derrida demostró que la constitución de una identidad siempre se basa en la exclusión de algo y el establecimiento de una jerarquía violenta entre los dos polos resultantes (2003, p. 19. El destacado es mío).

Asimismo, Larraín aclara que "el individuo se experimenta a sí mismo no directamente, sino indirectamente; se hace objeto de sí mismo sólo al tomar las actitudes de otros hacia él”, por tanto la identidad sería también esa "capacidad de considerarse a uno mismo como objeto y en ese proceso ir construyendo una narrativa sobre sí mismo". Larraín subraya: "la identidad es un discurso o narrativa sobre sí mismo construido en la interacción con otros mediante ese patrón de significados culturales" (2003, p. 32. El destacado es mío) ${ }^{17}$. De igual manera, para Hall, las identidades son "construidas de múltiples maneras a través de discursos, prácticas y posiciones diferentes, a menudo cruzados y antagónicos. Están sujetas a una historización radical, y en un constante proceso de cambio y transformación” (2003, p. 17). Según Hall,

las identidades tienen que ver con las cuestiones referidas al uso de los recursos de la historia, la lengua y la cultura en el proceso de devenir y no de ser, no 'quiénes somos' o 'de dónde venimos' sino en qué podríamos convertirnos, cómo nos han representado y cómo atañe ello al modo como podríamos representarnos. Las identidades, en consecuencia, se constituyen dentro de la representación y no fuera de ella (2003, p. 17-18. El destacado es mío).

Por lo tanto, "las identidades se construyen dentro del discurso y no fuera de él" (2003, p. 18. El destacado es mío) ${ }^{18}$.

Cabe destacar que en ese discurso o en esa narrativa sobre uno mismo, según Van Dijk "la gente se construye a sí misma como miembro de varias categorías y grupos (mujeres, minorías étnicas, ciudadanos de Estados Unidos, periodistas, ecologistas, etc.)” (1999, p. 152), ya que el sujeto se define por sus relaciones sociales, construyendo y exhibiendo simultáneamente sus roles sociales, como señala Van Dijk:

los usuarios del lenguaje utilizan activamente los textos y el habla no solo como hablantes, escritores, oyentes o lectores, sino también como miembros de categorías sociales, grupos, profesiones, organizaciones, comunidades, sociedades o culturas, interactúan como mujeres y hombres, negros y blancos, viejos y jóvenes, pobres y ricos, médicos y pacientes, docentes y

17. Según Curcó y Ezcurdia este papel central que cobra la narrativa se debe a varias razones: en primer lugar, se ha atribuido a la narración interior una función cognoscitiva en la organización de la experiencia, capaz de proveer la continuidad psicológica necesaria para la conformación de la identidad. Adicionalmente, las narraciones indican a qué le damos valor, señalan cómo organizamos y nos explicamos los sucesos y cómo nos describimos como personas de nuestras historias, a la par que nos insertan en (o nos separan de) los grupos sociales que nos rodean (2009, p. 18).

18. Curcó y Ezcurdia (2009) sostienen que dentro del enfoque discursivo, la identidad es concebida como "una construcción permanente que un sujeto realiza en su tarea continua de diferenciarse de otros e individuarse" (20) y como consecuencia natural de dicha concepción de la identidad, "es que la actividad discursiva juega un papel fundamental en la construcción, preservación y modificación de identidades" (23). 
estudiantes, amigos y enemigos, chinos y nigerianos, etc., y en la mayoría de los casos en complejas combinaciones de estos roles e identidades sociales y culturales $(2010$, p. 22 . El destacado es del original).

Aspecto en que se manifiesta lo que Restrepo llama, la multiplicidad de identidades:

Otro aspecto crucial en la conceptualización de la identidad refiere al hecho de su pluralidad y multiplicidad encarnada en individuos y colectividades concretas. En efecto, las identidades son múltiples y constituyen amalgamas particulares. No podemos decir que en un momento dado existe una sola identidad en un individuo o una colectividad específica, sino que en un individuo se dan una amalgama, se encarnan múltiples identidades; identidades de un sujeto nacionalizado, de un sujeto sexuado, de un sujeto 'engenerado' (por lo de género), de un sujeto 'engeneracionado' (por lo de generación), entre otros haces de relaciones. Desde la perspectiva del individuo, su identidad es múltiple y hay que entenderla precisamente en esas articulaciones, contradicciones, tensiones y antagonismos. De ahí que sea más adecuado hablar de identidades en plural (2012, p. 134. Los destacados son míos).

Así las cosas, siempre que hablamos o escribimos, dejamos patente desde cuáles identidades estamos hablando, desde qué locación cultural. Cada vez que hacemos uso del lenguaje tomamos posición, nos definimos y definimos al Otro también. El texto literario como expresión de un sujeto no está exento de esto, por el contrario cuenta con una amplia gama de recursos para lograr construir un Yo o un Nosotros con el cual como lectores nos identifiquemos y, al mismo tiempo, distanciarse de un Él o Ellos en cualquiera de las categorías con que solemos identificarnos, los diversos roles o identidades sociales y culturales que han indicado Van Dijk y Restrepo: sexo, género, etnia, edad, profesión, clase, etc. De ahí la importancia de analizar las construcciones identitarias que materializan los textos literarios.

Entonces, en qué fijarnos a la hora de estudiar las identidades. Su análisis deviene: en "estudiar la manera en que las formas simbólicas son movilizadas en la interacción para la construcción de una autoimagen" (Larraín, 2003, p. 32), lo que demanda también el estudio de la heteroimagen, puesto que identidad y alteridad son "recíprocamente constitutivas". Es por esta razón que siempre deben estudiarse los dos términos: "la identidad de un término no puede explorarse o ponerse en tela de juicio sin una investigación simultánea del segundo término" (Grossberg citado en Larraín, 19996, p. 153). En consecuencia, un paso metodológico importante e indispensable a la hora de elaborar un análisis literario en el tema de las identidades sería no solo el análisis de la construcción identitaria de un personaje, sino también la construcción que él mismo tiene de los otros personajes con quienes interactúa. Así como las construcciones que los otros personajes elaboran de sí mismos y de sus $\operatorname{Otros}^{19}$.

19. En relación con esto, Bajtín sostiene que "la literatura crea imágenes muy específicas de las personas, en las cuales el yo y el otro se combinan de un modo especial". Estas imágenes del ser humano que brinda la literatura "no pueden ser indiferentes" a la forma en que el ser humano existe, es decir, a la relación yo 
De acuerdo con Larraín, la construcción identitaria es un proceso que posee tres aspectos fundamentales: el cultural, el material y el social,

Cultural, porque los individuos se definen a sí mismos en términos de ciertas categorías compartidas, cuyo significado está culturalmente definido, tales como religión, género, clase, profesión, etnia, sexualidad, nacionalidad, que contribuyen a especificar al sujeto y su sentido de identidad. [...]. Es material en cuanto los seres humanos proyectan simbólicamente su sí mismo, sus propias cualidades en cosas materiales, partiendo de su propio cuerpo; se ven a sí mismos en ellas y las ven de acuerdo a [sic] su propia imagen. Es también un proceso social, porque la identidad implica una referencia a los 'otros' en dos sentidos. Primero, los otros son aquellos cuyas opiniones acerca de nosotros internalizamos, cuyas expectativas se transforman en nuestras propias auto-expectativas. Pero también son aquellos con respecto a los cuales queremos diferenciarnos (2003, p. 32. El destacado es mío).

En cuanto al aspecto material, Larraín sigue a Simmel, quien plantea que los seres humanos proyectan en las cosas materiales su sí mismo:

Toda propiedad significa una extensión de la personalidad; mi propiedad es lo que obedece a mi voluntad, es decir, aquello en lo cual mi sí mismo se expresa y se realiza externamente. $Y$ esto ocurre antes y más completamente que con ninguna otra cosa, con nuestro cuerpo, el cual por esta razón constituye nuestra primera e indiscutible propiedad (Simmel citado en Larraín, 2003, p. 33. El destacado es mío).

Por lo tanto, estos tres aspectos deberían ser contemplados a la hora de analizar las distintas construcciones identitarias. Especialmente, en el aspecto material, las propiedades y el consumo, así como la percepción que se tiene del propio cuerpo y el de los demás. Esto por cuanto su análisis pondrá de relieve quiénes son los otros, en su doble dimensión: los otros significativos y los otros de diferenciación. Los otros significativos son aquellos de quienes el sujeto internaliza las expectativas, actitudes y evaluaciones que de él tienen, "sólo las evaluaciones de aquellos otros que son de algún modo significativos para el sujeto cuentan verdaderamente para la construcción y mantención de su autoimagen" (2003, p. 34). Mientras que, los otros de diferenciación son precisamente aquellos de quienes el sujeto busca distanciarse y diferenciarse ${ }^{20}$.

Larraín advierte que a pesar de la gran importancia que tiene el otro para la construcción de la identidad, esta no es "puramente una construcción pasiva constituida por las expectativas de los otros", puesto que requiere no solamente de cómo los otros nos reconocen, sino también de un auto-reconocimiento, una función del reconocimiento de los otros que hemos internalizado. Por eso el estudioso dirá con Honneth: "la construcción de la identidad es un proceso

y otro, por lo cual al realizar un análisis de dichas imágenes debe evitarse "situarlas fuera de la relación yo-otro" (2000, p. 166).

20. Es importante destacar que de acuerdo con Larraín, la diferenciación constituye un proceso "indispensable para la construcción de la identidad", no así "la oposición hostil al otro" (2003, p. 35). 
intersubjetivo de reconocimiento mutuo" (Honneth, 1995 citado en Larraín, 2003, p. 34). Incluso, Larraín aclara que, en el caso de un adulto,

la imagen de sí mismo, aunque dependiente de diversas maneras de las evaluaciones de los otros, tiene normalmente fuerza bastante para existir con una autonomía relativa. Es decir, hasta un cierto punto el adulto ya ha construido su autoimagen sobre la base de una larga secuencia de evaluaciones previas ocurridas en su juventud (1996, p. 102) ${ }^{21}$.

Asimismo, el estudioso distingue dos tipos de identidades: individuales-personales y colectivas-culturales. Las identidades individuales "tienen contenidos psicológicos", mientras que, "las identidades colectivas no pueden describirse en términos psicológicos". De igual manera, sostiene que "las identidades individuales normalmente tienen un solo relato identitario más o menos integrado, las identidades colectivas normalmente poseen varios discursos identitarios" (2003, p. 36). Y, destaca que identidad cultural e identidad personal están íntimamente vinculadas, "en el sentido de que una cultura define una serie de categorías -como nación, sexualidad, clase, género, religión, etnia, etc.- que son los determinantes principales de la identidad personal" (Larraín, 1996, p. 93-94). De modo tal que la identidad cultural provee al individuo categorías para su multiplicidad de identidades personales, como destacan Van Dijk y Restrepo.

De ahí que Hall defina la identidad como

el punto de encuentro, el punto de sutura entre, por un lado, los discursos y prácticas que intentan 'interpelarnos', hablarnos o ponernos en nuestro lugar como sujetos sociales de discursos particulares y, por otro, los procesos que producen subjetividades, que nos construyen como sujetos susceptibles de 'decirse' (2003, p. 20. El destacado es mío).

Las identidades se construyen entonces como puntos de sutura entre una identidad asumida por el sujeto y otra asignada por la sociedad, el Otro, o un determinado grupo. Las identidades constituyen un punto de sutura entre las "prácticas de asignación e identificación" (Restrepo, 2012, p. 140. El destacado es mío), correspondiéndose la identificación con la identidad asumida.

Ahora bien, desde la teoría y crítica literarias podría decirse que las construcciones identitarias desde la categoría de género cuenta ya con una amplia tradición, la construcción de las identidades nacionales latinoamericanas han sido bastante estudiadas; mas no así las

21. En congruencia con esto, Bajtín señala que "todo lo que se refiere a mi persona, comenzando por mi nombre, llega a mí por boca de otros, con su entonación, dentro de su tono emocional y volitivo. Al principio tomo conciencia de mí mismo a través de los otros: de ellos obtengo palabras, formas, tonalidad para la formación de una noción primordial acerca de mí mismo. Elementos del infantilismo en la autoconciencia que permanecen a veces hasta el final de la vida (la percepción y concepción de sí mismo, de su cuerpo, rostro, del pasado)" (2000, p. 161-162). 
identidades étnico-culturales-raciales, las cuales entran en juego a la hora promover o desmantelar sistemas de dominación como el racismo. Es por este motivo que me centraré ahora en la identidad étnica o etnicidad. Al igual que la identidad en general, es una construcción social, variable, histórica, contextual y emerge en el contacto con el otro. Sin embargo, el concepto de etnicidad tiene su particularidad en que señala una filiación a una "especificidad cultural, física y social, manteniendo así un sentido de pertenencia" (Gutiérrez y Balslev, 2008, p. 20), se trata de un "querer pertenecer a un grupo o colectividad de manera simbólica, física o espiritual" (Gutiérrez y Balslev, 2008, p. 13).

Gutiérrez y Balslev sostienen que hay tres niveles que intervienen en el proceso de construcción étnica: subjetivo, grupal y estructural colectivo. La dimensión subjetiva tiene que ver con "la individualidad del sujeto, la conciencia de pertenecer a un grupo étnico, la creencia en una comunidad de origen común fundada en una similitud de valores culturales costumbres y experiencias que refieran a una memoria colectiva" (2008, p. 21. El destacado es mío). La grupal, se refiere a "las movilizaciones y acciones colectivas según las que se organizan y estructuran los grupos étnicos, es decir, la construcción política" (2008, p. 22. El destacado es mío). Y la estructural-colectiva, se vincula con "las construcciones estructurales de naturaleza social, económica y política que moldean las identidades étnicas individuales e influyen en los movimientos políticos-económicos" (2008, p. 22). Niveles a considerar a la hora de llevar a cabo un análisis de las construcciones identitarias étnico-culturales.

En este sentido, dentro del nivel subjetivo hay que considerar también un aspecto que los enfoques tradicionales de la etnicidad suelen dejar de lado: "la etnicidad se puede presentar no como una elección individual y subjetiva sino obligatoria y estructural que se tiene que enfrentar con o sin el consentimiento del individuo" (Gutiérrez y Balslev, 2008, p. 22. El destacado es mío). Es decir, la etnicidad comprendería para estos autores, no sólo la filiación manifiesta y voluntaria del individuo, sino también aquella que se le asigna. En este caso, el punto de sutura señalado por Hall se rompe. El equilibrio entre la identificación y la asignación se pierde, cayendo así en una pura asignación, que en lugar de identidad es "una práctica de estereotipia" (Restrepo, 2012, p. 140).

Ahora bien, abordar la construcción identitaria étnico-cultural demanda entonces un enfoque maximalista de la etnicidad, ya que esta no debe entenderse como cualidad única y exclusiva de las "minorías étnicas", de la cual los blancos están exentos, pues tal conceptualización materializa "una treta de la colonialidad del saber, controlada por blancos" (Mignolo 2015 en comunicación personal). 
Para Hall y Restrepo, "la etnicidad no sólo incluye las minorías étnicas, sino también ciertos grupos que, convencionalmente, han sido considerados sin ella". Ambos autores consideran que "el lugar desde el cual uno habla es la locación cultural que define la etnicidad" (Restrepo, 2004, p. 40). Hall plantea que la invisibilización de la etnicidad europea se debe a que los europeos se han construido a sí mismos a través de producir/inventar una exterioridad definida por un radical Otro. De manera que, como apunta Restrepo, "grupos, sujetos, comportamientos, expresiones y lenguajes han sido marcados en una exterioridad constituida para un lugar no-marcado, naturalizado e invisible" (Restrepo, 2004, p. 42).

"La constitución y existencia de esta invisibilidad de la etnicidad ha requerido un término marcado, considerado como paradigma de lo étnico"; pero, dado que, como bien recuerda Hall, el significado es relacional, "los términos marcados significan por su posición en relación con lo que está ausente, lo no marcado". Es por eso que Restrepo señala que tanto lo que "aparece como etnicidad (la etnicidad marcada) como lo que no es reconocido como tal (pero que es etnicidad, en el sentido de Hall) es necesariamente relacional, pero en posiciones asimétricas de visibilidades/invisibilidades y decibilidades/silencios”(Restrepo, 2004, p. 43).

Por esta razón, Restrepo considera que

para entender las identidades étnicas se debe analizar no sólo la producción de las locaciones étnicas a través de las cuales los individuos étnicamente marcados o no marcados son localizados sino también los continuos y contradictorios procesos mediante los cuales ellos avalan, reproducen o confrontan estas locaciones (2004, p. 63).

Como ha podido verse, las culturas resultan fundamentales en la construcción de las identidades, pues brindan un marco de "creencias, costumbres, leyes, formas de conocimiento y arte”, así como un "patrón de significados incorporados en formas simbólicas, incluyendo allí expresiones lingüísticas, acciones y objetos significativos, a través de los cuales los individuos se comunican y comparten experiencias" (Larraín, 2003, p. 31). Una cultura constituye entonces patrón de símbolos, signos y significados que en tanto tales, recuérdese, con Bajtín, Cros y Van Dijk, son absolutamente ideológicos. En otras palabras, la cultura podría ser vista como un lente que le brinda al individuo una manera para ver y percibir el mundo, y por tanto también una manera para verse y ver al Otro, es decir, construirse identitaria y étnicamente, así como construir al Otro.

\section{Racismo}


Si entendemos la literatura como práctica social, cultural y por tanto ideológica, que construye identidades, comprenderemos fácilmente que sea también un medio para producir y reproducir ideologías discriminatorias como el racismo, el sexismo, la homofobia y la xenofobia. Como anota Restrepo: "las identidades no sólo se refieren a la diferencia, sino también a la desigualdad y a la dominación. [...]. Las identidades no sólo están ligadas a principios clasificatorios, sino también a prácticas de explotación y dominio (2012, p. 137). Por lo tanto, la literatura en ese proceso de construir identidades materializa también ideologías, sean justas o nefastas como el racismo. Ante este panorama, se hace necesario un abordaje claro del racismo como sistema en el que pervive la colonialidad.

La colonialidad refiere al "esquema de pensamiento y marco de acción que legitima las diferencias entre sociedades, sujetos y conocimientos" (Restrepo y Rojas, 2009, p. 9). Este se extiende hasta el presente y opera a través de la naturalización de jerarquías que posibilitan la reproducción de relaciones de dominación con el fin de explotar el capital de los Otros, así como subalternizar y obliterar los conocimientos Otros. La colonialidad es "una estructura lógica del dominio colonial que subyace en el control español, holandés, británico y estadounidense de la economía y la política del Atlántico, desde donde se extiende a casi todo el mundo" (Mignolo, 2007, p. 33).

Mignolo plantea que es la modernidad la que crea la colonialidad, la cual instauró "los cimientos históricos, demográficos y raciales del mundo moderno/colonial”, dentro de los cuales operó una "categorización de individuos según su nivel de similitud o cercanía respecto de un modelo presupuesto de humanidad ideal” (2007, p. 41). De acuerdo con su tesis, Mignolo apunta que la colonialidad constituye el reverso de la modernidad, su lado oscuro y enterrado. Ambas son dos caras de una misma moneda. La modernidad es la visión europea de la colonialidad, ya que "desde su perspectiva, se refiere a un período de la historia que se remonta al Renacimiento europeo y al 'descubrimiento' de América o bien a la Ilustración europea” (2007, p. 31). Mientras que la colonialidad consiste en la percepción latinoamericana de la modernidad, pues es la perspectiva "del otro lado, de las excolonias portuguesas y españolas de América del Sur". De manera que la idea propuesta por los académicos e intelectuales del llamado Giro descolonial es que "el progreso de la modernidad va de la mano con la violencia de la colonialidad" (Mignolo, 2007, p. 31).

Como ha dicho Mignolo, "es precisamente la modernidad la que necesita y produce la colonialidad" (2007, p. 37). La matriz colonial de poder fue engendrada, según Mignolo por "la combinación de la ideología de expansión del cristianismo de Occidente con la transformación del comercio derivada de la posesión de tierra y la explotación a gran escala de mano de obra 
para producir mercancías destinadas a un nuevo mercado mundial” (2007, p. 55). En este "proceso de invención de América", fue necesaria "la construcción ideológica del racismo" (2007, p. 40).

De manera que el racismo se inscribe dentro de la colonialidad:

la idea de raza es, con toda seguridad, el más eficaz instrumento de dominación social inventado en los últimos 500 años. Producida en el mero comienzo de la formación de América y del capitalismo, en el tránsito del siglo XV al XVI, en las centurias siguientes fue impuesta sobre toda la población del planeta como parte de la dominación colonial de Europa (Quijano, 1999, p.141).

Ya que,

extinguido el colonialismo como sistema político formal, el poder social está aún constituido sobre la base de criterios originados en la relación colonial, pues desde entonces todas las determinaciones y criterios de clasificación social de la población del mundo y su ubicación en las relaciones de poder actúan en interrelación con el racismo y el etnicismo (Quijano, 1992, p. $1)$.

Así las cosas, el racismo se observa como práctica de violencia no solo física, sino también simbólica que comprende lo que desde las Epistemologías del Sur se ha llamado violencia epistémica (Mignolo), epistemicidio (Santos) y racismo epistémico (Grosfoguel): ejerce una violencia epistémica que niega todo lo Otro: otras maneras de saber, de ser, de sentir y de hacer, exterminándolas o asimilándolas (2007, p. 30 y 2010, p. 12. El destacado es mío). El epistemicidio fue mucho más extendido que el mismo genocidio, ya que "ocurrió siempre que se pretendió subalternizar, subordinar, marginalizar o legalizar prácticas y grupos sociales que podrían constituir una amenaza para la expansión capitalista" y sus principales víctimas han sido: indígenas, negros, mujeres, trabajadores y minorías étnicas, religiosas y sexuales (Santos, 1998, p. 431). El epistemicidio dio al traste con el derecho original al conocimiento, a través de él la modernidad occidental suprimió este derecho y creó su conocimiento imperial (Santos, 2010, p. 89). El racismo epistémico

se refiere a una jerarquía de dominación colonial donde los conocimientos producidos por los sujetos occidentales (imperiales y oprimidos) dentro de la zona del ser se consideran a priori como superiores a los conocimientos producidos por los sujetos coloniales no-occidentales en la zona del no-ser. La pretensión es que el conocimiento producido por los sujetos pertenecientes a la zona del ser, ya sea desde el punto de vista derechista del 'Yo' imperial o desde el punto de vista izquierdista del 'Otro' oprimido occidental dentro de la zona del ser, por esta sola razón se considere universalmente válido para todos los contextos y situaciones en el mundo. Esto conduce a una epistemología universalista imperial/colonial tanto de derecha como de izquierda en la zona del ser al no tomarse en serio la producción teórica producida desde la zona del no-ser e imponer como diseño global/imperial sus esquemas teóricos pensados para realidades muy distintas a las situaciones de la zona del no-ser (Grosfoguel, 2012, p. 98). 
Grosfoguel sigue el concepto fanoniano de racismo, siendo que para Fanon,

hay una zona de no-ser, una región extraordinariamente estéril y árida, una rampa esencialmente despojada, desde la que puede nacer un auténtico surgimiento. En la mayoría de los casos, el negro no ha tenido la suerte de hacer esa bajada a los verdaderos Infiernos (Fanon, 2009, p. 42. El destacado es mío).

Fanon apunta de esta manera que el hombre negro ha sido relegado a una zona de no-ser de la que debe salir: "el negro es un hombre negro; es decir que, gracias a una serie de aberraciones afectivas, se ha instalado en el seno de un universo del que habrá que sacarlo (2009, p. 42). Y dicha zona de no-ser está marcada por una línea: "Entre el negro y el blanco se traza la línea de mutación. Se es blanco como se es rico, como se es bello, como se es inteligente. (2009, p. 71).

A partir de las reflexiones de Fanon, Grosfoguel explica el racismo como "una jerarquía global de superioridad e inferioridad sobre la línea de lo humano que ha sido políticamente producida y reproducida como estructura de dominación durante siglos por el 'sistema imperialista / occidentalocéntrico / cristianocéntrico / capitalista / patriarcal /moderno / colonial"” (Grosfoguel, 2012, p. 93). De acuerdo con este concepto de racismo,

las personas que están arriba de la línea de lo humano son reconocidas socialmente en su humanidad como seres humanos con subjetividad y con acceso a derechos humanos/ciudadanos/civiles/laborales. Las personas por debajo de la línea de lo humano son consideradas sub-humanos o no-humanos, es decir, su humanidad está cuestionada y, por tanto, negada (Grosfoguel, 2012, p. 93).

Así, el racismo o la inferiorización puede marcarse por color, etnicidad, lengua, cultura o religión, dependiendo de "la historia local/colonial" (2012, p. 93). La inferiorización que marca los cuerpos, los racializa, a algunos como superiores y a otros como inferiores. "El punto importante para Fanon es que aquellos sujetos localizados en el lado superior de la línea de lo humano viven en lo que él llama la 'zona del ser', mientras que aquellos sujetos que viven en el lado inferior de esta línea viven en la 'zona del no-ser"” (2012, p. 94), de manera que "la raza constituye la línea divisoria transversal que atraviesa y organiza las relaciones de opresión de clase, sexualidad, y género a escala global". Si bien la interseccionalidad de estas relaciones de dominación (feministas negras) o la colonialidad (Quijano) se da en ambas zonas del mundo, Fanon señala que la

experiencia vivida de las diversas opresiones y la manera particular como ocurre la interseccionalidad es diferente en la zona del ser en comparación con la zona del no-ser. En la zona del ser, los sujetos, por ser racializados como seres superiores, no viven opresión racial, sino privilegio racial. [...]. En la zona del no-ser, debido a que los sujetos son racializados como inferiores, ellos viven opresión racial en lugar de privilegio racial. Por tanto, la opresión de clase, 
sexualidad y género que se vive en la zona del no-ser es cualitativamente distinta a como estas opresiones se viven en la zona del ser (Grosfoguel, 2012, p. 94. El destacado es mío).

Como indica Grosfoguel, siguiendo a Santos, la manera como se gestionan los conflictos en la zona del ser es a través de lo que él llama mecanismos de regulación y emancipación: “códigos de derechos civiles/humanos/laborales, relaciones de civilidad, espacios de negociaciones, y acciones políticas que son reconocidas al 'Otro' oprimido en su conflicto con el 'Yo' dentro de la zona del ser, discursos de libertad, autonomía e igualdad', es decir, métodos no violentos, "la violencia siempre se usa en momentos excepcionales" (2012, p. 95). Mientras que en la zona del no-ser, "las poblaciones son deshumanizadas", lo que permite al "Yo" imperial/capitalista/masculino/heterosexual y su sistema institucional para gestionar y administrar los conflictos recurrir a la violencia y a la apropiación abierta y descarada". Los conflictos en la zona del no-ser son gestionados por la violencia perpetua y solamente en momentos excepcionales se usan métodos de regulación y emancipación.

Así las cosas, para Fanon y para Santos,

la zona del ser es el mundo imperial, que incluye no solamente a las élites imperiales, sino también a sus sujetos oprimidos occidentales tanto en los centros como en las periferias del sistema-mundo, mientras que la zona del no-ser es el mundo colonial con sus sujetos oprimidos no-occidentales. Pero para Fanon y Santos, igualmente, la zona del no-ser es heterogénea y estratificada. Lo que esto quiere decir es que en la zona del no-ser, además de la opresión que los sujetos viven por parte de los sujetos en la zona del ser, hay también opresiones ejercidas dentro de la zona del no-ser entre los sujetos pertenecientes a dicha zona (Grosfoguel, 2012, p. 97. El destacado es mío).

De aquí que de cara a un análisis literario en materia de identidades étnico-culturales sea pertinente determinar la ubicación, tanto de los personajes como del narrador y el autor de carne y hueso en una u otra zona.

Ahora bien, qué sucede cuando alguien osa señalar un texto literario como racista. Múltiples y variadas excusas emergerán de aquellos que desconocen la teoría que se ha producido sobre este fenómeno y que se han quedado con una cómoda y reducida perspectiva histórica de cómo surge y cómo es en los tiempos que corren, es por esa razón que me parece urgente ofrecer acá una conceptualización no solo teórica sino también histórica-cultural del racismo.

En cuanto a los orígenes del racismo, los autores del Giro los sitúan en el siglo XV, en la península ibérica:

existía ya a fines del siglo XV en la península ibérica el discurso acerca de la 'pureza de sangre'. Este discurso era una forma de proto-racismo movilizado contra las poblaciones musulmanas y judías durante la conquista colonial por parte de la monarquía católica para destruir el poder político musulmán en la península ibérica, territorio conocido como Al-Ándalus (Grosfoguel, 2012, p. 87). 
Y una vez "descubierta” América, "la vieja discriminación religiosa del medioevo europeo tales como los viejos discursos antisemitas (judeófobos e islamófobos) fueron movilizados contra las poblaciones americanas" (Grosfoguel, 2012, p. 88). Según Grosfoguel, el racismo religioso contra los judíos y moros no discutía su humanidad, ya que se creía que eran humanos, pero creyentes de un Dios equivocado; sin embargo, la descripción de Colón de que los "indios" no tenían religión

los saca aparte de la categoría de lo humano. Como la religión es algo universal en los humanos, la falta de la misma no denota la falsedad de la proposición, sino al contrario, el hecho de que hay sujetos que no son del todo humanos en el mundo. [...].

Con la colonización de las Américas estos viejos discursos de discriminación religiosa medieval mutaron rápidamente, transformándose en discursos de discriminación racial moderna. Si bien la palabra 'raza' no era usada en la época, sí era un debate racista en el sentido usado por el racismo científico del siglo XIX en la medida en que el debate teológico del siglo XVI tenía la misma connotación del debate cientificista del siglo XIX, es decir, era un debate acerca de la humanidad de unos y la animalidad de los otros articulado por las propias instituciones de estado que en la época era la monarquía católica castellana (2012, p. 89-90).

Es decir, "el discurso racista biológico es una secularización en el siglo XIX del discurso racista teológico del siglo XV" (Grosfoguel, 2012, p. 91). Lo que pone en evidencia que el racismo no es un sistema invariable, por el contrario, necesita metamorfosearse para subsistir. Esto explica por qué a pesar de que la existencia de razas humanas ha sido descartada, el racismo pervive, así como la colonialidad. Teóricos como Todorov (1991), Quijano (1992 y 1999), Javaloy (1994), Taguieff (1998), Wieviorka (1998 y 2007), Van Dijk (1988, 1995, 2000, 2003 y 2007), Duncan (1988 y 2001), García (2004), Hering (2007), Morales (2008), Casaús Arzú (1998 y 2010) y Grosfoguel (2012) han apuntado que el racismo biológico fue utilizado para legitimar la superioridad de unas razas sobre otras: la biología y la antropología establecieron jerarquías y divisiones que a través del discurso científico se llegaron a naturalizar; pero una vez que esos argumentos cayeron "se recurrió al argumento de las culturas, a través de las diferencias como formas de reafirmar la superioridad de unas sobre otras" (Morales, 2008, p. 73).

Para Wieviorka,

el racismo consiste en caracterizar un conjunto humano mediante atributos naturales, asociados a su vez a características intelectuales y morales aplicables a cada individuo relacionado con este conjunto y, a partir de ahí, adoptar algunas prácticas de inferiorización y exclusión (2009, p. 13).

El racismo no es un fenómeno estático, por el contrario,

se ha transformado en el tiempo, y la distancia entre sus expresiones clásicas, que apelan a la ciencia, y sus formas contemporáneas, que recurren cada vez más a la idea de 'diferencia' y de incompatibilidad de las culturas, es muy grande (Wieviorka, 2009, p. 14). 
Gracias a esta capacidad de transformación, el racismo, sigue en pie, no es algo pasado, ni mucho menos superado: "el racismo pertenece al presente de la humanidad" (Wieviorka, 2009, p. 16). A continuación, presento diferentes aristas teóricas desde las cuales se ha abordado el racismo, lo cual nos posibilita una visión más global del fenómeno, así como su identificación a pesar de los distintos rostros que toma, todos los cuales sirven al mismo objetivo: "legitimar la exclusión de los otros" (García, 2004, p. 93).

De acuerdo con Wieviorka, el racismo como práctica es anterior al concepto, mismo que surge en el período de entreguerras, imponiéndose en el lenguaje corriente de las sociedades occidentales, y luego de todo el planeta, a lo largo de los años de la posguerra. En concordancia con los estudiosos del Giro, Wieviorka señala que el fenómeno hunde sus raíces en el siglo XV, con la expansión europea y la colonización y desde su perspectiva, "el racismo es indisociable de la modernidad" (2009, p. 22).

Ahora bien, según Wieviorka, en la medida en que está asociado a la modernidad, el racismo puede abordarse de dos maneras: como un fenómeno ideológico, conjunto de doctrinas e ideas; o como sus modalidades concretas: masacres, explotación, discriminación y segregación, o al decir de García, esta otra manera "se enfoca en las realidades sociales del racismo más que en las ideas que le sirven de apoyo" (2004, p. 77). Para efectos de analizar la materialización del racismo en la literatura, juzgo pertinente complementar ambas maneras.

La primera vertiente ideológica y doctrinaria es la que inicia a finales del siglo XVIII como racismo científico o clásico, es decir, se difunde la idea "de una diferencia esencial, inscrita en la naturaleza misma de los grupos humanos, o sea, en sus características físicas" $(2009 \text {, p. } 24)^{22}$. Wieviorka señala que la colonización y el imperialismo, así como la nación y los nacionalismos se conjugan para dar pie a estas ideologías racistas, que se "asientan en la convergencia de todos los campos del saber" (2009, p. 25): viajeros, escritores, poetas, filósofos, científicos, anatomistas, físicos, historiadores, filólogos y teólogos pusieron su cuota para la consolidación del racismo.

Se trata, sea cual sea el saber descubierto o convocado, de demostrar la superioridad de la 'raza' blanca sobre las otras 'razas', de clasificar las razas humanas siguiendo la clasificación de las

22. De aquí que sea tan importante para este análisis fijarse en el retrato físico, intelectual y moral de los personajes afrodescendientes y blancos, pues la imagen que se nos dé de ellos, nos dará el punto desde el que son mirados y percibidos. En la percepción entrarían también los otros sentidos como el olfato, pues "los sentidos cobran el papel de guías y controladores, de aviso. Los sentidos nos señalan la frontera, pero al mismo tiempo nos consuelan de que 'los otros' son 'diferentes' y pueden ser distinguidos. En el caso de las diferencias culturales no visibles el miedo y la prevención son mayores, los fantasmas se disparan [...] ya que no hay una frontera clara y distinguible para encerrarlos o eludirlos" (Perceval, 2013, p. 22). 
especies propuesta por Linneo; y de mostrar, también, que 'la mezcla' es fuente de decadencia para la raza superior $(2009$, p. 26$)$.

Así, surgen en Europa una serie de trabajos pretendidamente científicos con el afán de apoyar las clasificaciones, jerarquías y taxonomías que apuntalarán la superioridad europeablanca. Posteriormente, a finales del siglo XIX las ideas de Herbert Spencer y Charles Darwin se conjuntan y dan lugar al darwinismo social, que confluye con el eugenismo impulsado por Francis Galton y se promueven las ideas racistas de que "las características fijas de la raza autorizan que un grupo racial se mantenga mediante luchas eliminando los especímenes impuros" (Wieviorka, 2009, p. 27). ${ }^{23}$ Para este momento, dichas ideas ya habían cruzado el Atlántico y Estados Unidos aportaba nuevos "científicos" en las filas del racismo, pues "en tanto conjunto de doctrinas e ideologías, el racismo clásico es también un fenómeno transnacional en el que las ideas sobre las razas circulan intensamente desde el Antiguo Mundo hacia el Nuevo" (Wieviorka, 2009, p. 29).

Este racismo científico propone que a las características biológicas o físicas de las 'razas', corresponderían "capacidades psicológicas e intelectuales, a la vez colectivas y válidas para cada individuo" (Wieviorka, 2009, p. 29). Sin embargo, evolucionó: a principios del siglo XIX, "las clasificaciones de las razas se fundan sobre todo en los atributos fenotípicos (color de la piel, tipo de cabellera, forma de la nariz y otras características del organismo que se manifiestan a la observación)", luego se detiene en el esqueleto y particularmente en el cráneo y, finalmente, en el contexto del desarrollo de los nacionalismos la distinción de las razas dentro de la Europa misma sirve "para justificar discursos y conductas que pretenden minimizar a los judíos, a los irlandeses, a los vascos" (Wieviorka, 2009, p. 30). Si bien el nazismo "marca el apogeo de este poderoso movimiento de ideas", después de la Segunda Guerra Mundial y "la toma de conciencia de lo que fue la barbarie nazi" (Wieviorka, 2009, p. 31), estas ideas no desaparecen, pero sí quedan deslegitimadas como crímenes, con lo cual aunado al trabajo de nuevos científicos y genetistas, se derrumba el soporte científico de 'las razas', aunque, como se dijo al inicio de este apartado, el racismo no haya desaparecido.

A pesar de que la idea de raza haya perdido su soporte científico, como apunta Quijano, no por eso ha sido eliminada del imaginario social. El colonialismo ha muerto, pero la colonialidad pervive y en ella la idea de raza y el racismo: “el 'racismo' en las relaciones sociales cotidianas no es, pues, la única manifestación de la colonialidad del poder. Pero es, sin duda, la más perceptible y omnipresente" (1999, p. 142). Para Quijano resulta

23. Ideas que calarán en la propuesta de La raza cósmica (1925), de José Vasconcelos. 
realmente notable que para la abrumadora mayoría de la población mundial, incluidos los opositores y las víctimas del racismo, la idea misma de 'raza', como un elemento de la 'naturaleza' que tiene implicaciones en las relaciones sociales, se mantenga virtualmente intocada desde sus orígenes (1999, p. 143).

Tal como dirá, años después, García: "resulta muy significativo que, a pesar de que todos los descubrimientos científicos descartan la existencia de las 'razas', este concepto perviva como una verdad incuestionable para casi todo el mundo" (2004, p. 35) y sostiene que el lenguaje y la sociedad se empeñan en mantener vivos problemas como el racismo (2004, p. 14), "porque una vez establecido un imaginario cultural, con demostración científica incluida, la sociedad misma se resiste a abandonarlo, sobre todo si desde él cree seguir teniendo la explicación de lo que pasa" (2004, p. 15).

Así, a finales de los años 60, los investigadores apuntan una transformación en el pensamiento racista "que apela a nuevos conceptos y análisis para fundamentarlo y explicarlo: racismo institucional (en instituciones o políticas), racismo manifiesto (creencia en la inferioridad genética del otro y un rechazo a cualquier contacto personal), racismo sutil (formas de racismo veladas frente a sus expresiones tradicionales, más explícitas), neorracismo-racismo cultural-racismo diferencialista", los cuales "respaldan la idea de que el racismo moderno insiste más sobre la diferencia de las 'razas' que sobre la desigualdad, esto es, sobre la cultura de la que serían base, que sobre su naturaleza físico-biológica (García, 2004, p. 76) ${ }^{24}$.

El discurso de Enoch Powell en 1968, y la creación del partido de extrema derecha National Front, en Reino Unido, marcan "la entrada de un racismo renovado, cuyo primer y más importante analista será Martin Barker”. Es Barker el primero, según Wieviorka, en hablar de un nиevo racismo, que pasó de la "inferioridad biológica a la diferencia cultural", y

24. Sobre el racismo institucional referiremos brevemente que surge en 1967 en Estados Unidos, de la mano de Stokely Carmichael y Charles V. Hamilton, quienes postulan que el racismo funciona en su país de manera no declarada e institucional, implícita, por cuanto sus mecanismos no son socialmente percibidos, ya que se trata de un problema social-estructural (Wieviorka, 2009, p. 37). Sin embargo, a esta conceptualización del racismo se le ha objetado que al ver el problema como estructural o sistemático, se disocia actor y sistema, "sugiriendo que el racismo también puede funcionar sin que intervengan prejuicios u opiniones racistas" (Wieviorka, 2009, p. 38). Asimismo, se le ha objetado que se centra en los efectos del racismo, mientras que mantiene camufladas e inidentificables las causas del racismo (Wieviorka, 2009, p. 40). Wieviorka señala a este respecto que "la utilidad de la noción de racismo institucional consiste en subrayar las formas no flagrantes o brutales del racismo, es decir, sus expresiones veladas, al transitar por las instituciones; pero se vuelve insuficiente cuando hace del racismo un fenómeno abstracto, que parece que se sustenta en mecanismos abstractos, sin actores" $(2009$, p. 41$)$. 
a partir de ese momento, la argumentación racista ya no se funda en la jerarquía sino en la 'diferencia', ya no en los atributos naturales atribuidos al grupo racializado sino en la cultura, su lengua, su religión, sus tradiciones y sus costumbres $(2009$, p. 42$){ }^{25}$

Este nuevo racismo "expresa un sentimiento de amenaza sobre la homogeneidad nacional". El enfoque de Barker obtiene en Gran Bretaña una importante aceptación de investigadores como Paul Gilroy, desde una tradición más o menos marxista y en relación con el pensamiento de Franz Fanon, "en el que ya se encontraba la denuncia del racismo cultural” (Wieviorka, 2009, p. 43), y en Francia de Pierre André Taguieff quien planteaba el racismo diferenciado. Por otra parte, en Estados Unidos, también durante los años 70, surge el concepto bastante cercano al anterior, de racismo simbólico, que designa "las formas menos ostensibles o flagrantes del fenómeno, y en particular, las variantes contemporáneas del prejuicio hacia los negros" (Wieviorka, 2009, p. 44).

Así, los importantes libros de Barker y de Taguieff, a los cuales se puede agregar el de Étiene Balibar e Immanuel Wallerstein o los trabajos de ciencias políticas y de psicología social de los investigadores estadounidenses, subrayan bruscamente el paso del racismo clásico, científico a un racismo 'nuevo', 'cultural', 'diferencialista' y 'simbólico': un 'neorracismo' [...]. El Otro según esta perspectiva, es percibido como el que no tiene ningún lugar en la sociedad de los racistas, es decir, que se le niegan sus valores y su ser cultural" (Wieviorka, 2009, p. 44-45).

De cara a la tesis de Taguieff que distancia el racismo clásico científico del racismo contemporáneo cultural, "para examinar la idea de un cambio radical", Wieviorka propone "que existen no dos racismos, sino dos lógicas" del racismo: universalista y diferencialista. La lógica universalista "disuelve la raza en las relaciones sociales y hace del grupo caracterizado por la raza una clase social, una modalidad extrema del grupo explotado" (asimilación). Mientras que la lógica diferencialista, "tiende a rechazar los contactos y las relaciones sociales, nos remite a la imagen de exterioridad radical de los grupos humanos", en este último caso, se puede mantener relación con el Otro mientras se mantenga alejado (distanciación) o se emprenden procesos de exterminación del Otro (destrucción) (2009, p. 48). Aunque, Wieviorka sostiene que las grandes experiencias históricas del racismo, como el apartheid y el nazismo, combinan ambas lógicas, por lo que no sería legítimo hablar de nuevo racismo para dar cuenta de una lógica de pura diferenciación, a pesar de que en la actualidad sea esta la más fuerte $(2009$, p. 65).

Con respecto a las expresiones concretas del racismo, Wieviorka se aboca al estudio de:

25. En este sentido, Mignolo apunta que "el racismo ha sido una matriz clasificatoria que no solo abarca las características físicas del ser humano (sangre y color de la piel, entre otras) sino que se extiende al plano interpersonal de las actividades humanas, que comprende la religión, las lenguas y las clasificaciones geopolíticas del mundo" (2007, p. 42). 
a) el prejuicio, que consiste en las representaciones del Otro como del exogrupo, lo cual "amplía las diferencias y desemboca en estereotipos susceptibles de alimentar o justificar actitudes discriminatorias" (2009, p. 72). El prejuicio se nutre de la ignorancia y el desconocimiento, para presentar imágenes distorsionadas y rebajadas del Otro (2009, p. 74). Asimismo, Wieviorka sigue a Van Dijk cuando este señala que el prejuicio "dota a los miembros del grupo dominante de los medios con que fundar su racionalización de su dominación, asegurando así su reproducción" (2009, p. 76). Para Wieviorka, "en la medida en que la expresión explícita del prejuicio está prohibida, quienes tienen dicho prejuicio sobre todo en los sectores educados de la población, a veces lo disimulan detrás de otros argumentos”. Además, el prejuicio puede ser previo al acto, aunque el paso al acto "exige condiciones favorables, en particular morales y políticas" (2009, p. 78).

b) la segregación: la segregación racial es a su vez un proceso y su resultado, "que sufre un grupo mantenido a distancia, localizado en espacios propios que le son reservados, enclaves, guetos, territorios de uno u otro tipo", distanciación geográfica que se puede ver acompañada con "medidas de circulación restrictivas" y la "prohibición de entrar en determinados espacios o salir de los que les tienen reservados" (2009, p. 79). La segregación corresponde a una lógica de diferenciación (2009, p. 83).

c) la discriminación: aquí también nos encontramos ante un proceso y su resultado, consiste en "poner de relieve la raza para otorgarle a un grupo un tratamiento diferenciado", además "se puede ejercer en todos los ámbitos de la vida social” (2009, p. 83). La discriminación corresponde a una lógica universalista.

d) la violencia: para Wieviorka el racismo "siempre es una violencia", ya que "constituye una negación de quien resulte víctima, es decir, una alteración de la parte de humanidad de la que cada cual es portador". De este modo, el racismo se concreta en dos tipos de violencia, una simbólica, "cuando se afecta a la integridad moral de una persona sin alterar, sin embargo, directamente su participación en la vida social, política o económica, cuando dicha violencia es del orden del prejuicio o de la simple expresión del odio, sin consecuencias sobre su integridad física" (2009, p. 87) y una física, sangrienta que bien puede ser política o infrapolítica ("proveniente de actores definidos en términos sociales, económicos y culturales pero fuera del espacio político") (2009, p. 89).

Finalmente, desde los Estudios Críticos del Discurso (ECD), Van Dijk indica que este nиеvo racismo tiene sus características particulares, pues una vez que los grupos minoritarios redujeron el poder exclusivo del grupo blanco (con movimientos como los Derechos civiles y el Black power), las condiciones de las actitudes y parte de la legitimación de la discriminación y 
opresión clásicas tenían que cambiar con el fin de mantenerse consecuentes con los profesados valores de igualdad étnica o racial. Por lo tanto "para que el grupo blanco mantuviera su control a pesar de los cambios en los medios de poder y sus fundamentos ideológicos, las relaciones de dominación debían transformarse en relaciones más sutiles e indirectas” (1988, p. 139). Además, "el movimiento pro derechos humanos, las leyes antidiscriminación, la política de igualdad de oportunidades y las tímidas modalidades de acción positiva han contribuido a atenuar las manifestaciones más contundentes y descaradas del racismo" (1997, p. 26).

Según la noción de Van Dijk, el racismo no compete únicamente a "las ideologías de supremacía racial de los blancos, ni a la ejecución de actos discriminatorios como la agresión evidente o flagrante", sino también a "todos los actos y concepciones sociales, procesos, estructuras o instituciones que directa o indirectamente contribuyen al predominio del sector blanco y a la subordinación de las minorías” (1997, p. 24). Nótese que Van Dijk habla aquí desde un lugar de enunciación europeo, puesto que la mayoría es blanca y la minoría no lo es. Sin embargo, el estudioso señala en otro texto que

en América Latina, no se trata de una mera cuestión de blancos versus no blancos, sino más bien de una sutil escala gradual de varias formas de ser más o menos europeo, africano o de rasgos indígenas. Siempre que sea pertinente, ser lo más parecido al fenotipo europeo (es decir, 'más blanco') tiende a ser asociado con un mayor prestigio y estatus, lo que está correlacionado con un mayor poder y una posición cultural y socioeconómica mejor (2007, p. 25).

De igual modo, para el estudioso, el racismo incluye el etnicismo, es decir, "el sistema de predominio de un grupo étnico que se basa en la categorización mediante criterios culturales, la diferenciación y la exclusión, entre los que se encuentran el lenguaje, la religión, las costumbres o las concepciones del mundo", esto por cuanto "a menudo los criterios étnicos y raciales son inseparables dentro de los sistemas de predominio" (1997, 24), aspecto en que coincide con lo planteado por Wieviorka y Mignolo, para quienes el racismo trasciende lo meramente físico y da paso a lo cultural.

Para Van Dijk el racismo "no es innato, sino que se aprende", y en tanto "proceso de adquisición ideológica y práctica ha de tener sus fuentes” (2007, p. 25). El racismo y la discriminación nacen en las élites económicas, políticas y culturales (políticos, catedráticos, editores, jueces, oficiales, burócratas y directivos de primera), de manera sutil, ya que lo directo y explícito sería políticamente incorrecto. Estas distribuyen su discurso por medio de los Aparatos Ideológicos de Estado (AIE) ${ }^{26}$ como: la educación pública, la investigación científica,

26. Althusser distingue entre el Aparato Represivo de Estado (ARE), constituido por instituciones como: el ejército, la policía, los tribunales, las prisiones, etc. las cuales funcionan mediante la violencia. Los Aparatos Ideológicos de Estado (AIE), contrario al ARE, constituyen una pluralidad, provienen del 
las editoriales, las tecnologías de la comunicación y los medios masivos, y así lo hacen llegar a la población en general, la cual llega a interiorizarlo y reproducirlo sutilmente o de forma explícita, "de forma descubierta utilizando expresiones ofensivas, derogatorias, insultos, groserías u otras formas de discurso que explícitamente expresan y promulgan la superioridad y falta de respeto" (1988, p. 10) en chistes, grafitis, dichos o conversaciones cotidianas e incluso se puede llegar a otras formas de racismo como los actos: golpes, linchamientos, segregación, expulsión y exterminio. En síntesis, la tesis de Van Dijk es que existe un racismo de élite que es vertido sobre el pueblo a través de los AIE, ya que estas controlan los discursos públicos, produciendo y reproduciendo un racismo popular y cotidiano que asegura el círculo del racismo. ${ }^{27}$

Ya que el racismo es aprendido, dicho proceso de aprendizaje "es, en gran medida discursivo", pues se basa en "la conversación y los relatos de todos los días, los libros de texto, la literatura, las películas, las noticias, los editoriales, los programas televisivos, los estudios científicos, etc.”; si bien puede aprenderse también a través de la observación y la imitación, “esas prácticas también deben ser explicadas, legitimadas o sostenidas discursivamente" (2007, p. 25). El discurso funciona entonces como la interfaz entre los subsistemas social y cognitivo del racismo, pues el racismo no se limita a una ideología o a formas visibles de prácticas discriminatorias, sino que comprende un sistema social de dominación étnica, el cual está constituido por dos subsistemas, uno social y otro cognitivo: el social se manifiesta en dos niveles. A nivel micro: con prácticas sociales discriminatorias. Y a nivel macro: en relaciones de abuso de poder por parte de grupos dominantes, organizaciones e instituciones dominantes. El cognitivo sugiere que el racismo posee una base mental expresada en modelos de representación arraigados en prejuicios, estereotipos e ideologías racistas. Esto permite señalar que las prácticas discriminatorias no siempre son intencionales, sino que suponen representaciones mentales socialmente compartidas y negativamente orientadas con respecto a una representación positiva del Nosotros y una representación negativa de Ellos. De ahí que sea imperioso el análisis y desenmascaramiento de estos discursos.

Van Dijk apunta que existen dos modalidades de discurso racista:

dominio privado como: las iglesias, los partidos, los sindicatos, las familias, algunas escuelas y las instituciones culturales; no funcionan con violencia, sino mediante ideología, la cual es instaurada por la clase dominante (2004, pp. 115-155).

27. Las élites también pueden ser "quienes ejecutan, controlan o condonan muchos de los actos racistas sutiles u obvios que definen el sistema del racismo cotidiano", por ejemplo: cuando un blanco no se involucra activamente en una de estas modernas modalidades de segregación, agresión, menosprecio o marginación, su participación en el acto racista consiste en adoptar una actitud pasiva, aquiescente, ignorante o indiferente respecto a la discriminación étnica o racial (1997, p. 25). Dado que las élites son las principales responsables del racismo, por estar en su cúspide, es también allí donde el cambio tiene que comenzar. 
a) discurso racista dirigido a los Otros étnicamente diferentes, es decir, consiste en la forma en que el grupo dominante interactúa verbalmente con los otros, representados como minorías étnicas, inmigrantes, refugiados. El cual se puede exponer de dos maneras: una abierta y explícita, que resulta ser ofensiva, agresiva, insultante, degradante, grosera y que expresa superioridad y falta de respeto hacia el otro. Y otra encubierta, sutil, implícita, indirecta que se manifiesta en las siguientes prácticas de interacción verbal: negarse a dar la palabra a alguien de la minoría, interrumpirle indebidamente, ignorar sus temas sugeridos, centrarse en temas que suponen propiedades negativas del grupo étnico minoritario, hablar muy ruidosamente, mostrar signos de aburrimiento con la cara, evitar mirar a su interlocutor a los ojos, utilizar tono de soberbia, mismas que se consideran desviadas o inaceptables para ser utilizadas con miembros del propio grupo (endogrupo): quien los llegue a utilizar contra su propio grupo es tachadotildado de grosero, maleducado (2007a, p. 10).

b) Discurso racista sobre los otros étnicamente diferentes: se puede presentar en la conversación cotidiana, diálogos organizativos (debates parlamentarios), textos escritos, documentos multimedia, eventos comunicativos (espectáculos televisivos, películas, noticias, editoriales, libros de textos, publicaciones académicas, leyes, contratos). Esta forma discursiva se presenta de las dos siguientes maneras: Como una autopresentación positiva del NOSOTROS: busca mitigar la representación positiva de los Otros, por ejemplo: "Nosotros somos solidarios, le hemos abierto las puertas, los hemos acogido en nuestra propia casa, y miren cómo nos pagan", expresando un favoritismo por el endogrupo. Y, como una presentación negativa de los OTROS: busca evitar una posible imagen negativa de Nosotros mismos, como en "Si ellos hubieran sido más sensatos, si hubieran utilizado el sentido común, si en lugar de...", menoscabando al exogrupo. Ambas formas discursivas conforman lo que Van Dijk ha denominado el cuadrado ideológico, se trata de un discurso que pretende resaltar lo positivo del YO a la vez que soslaya u oculta lo negativo, mientras resalta lo negativo del OTRO y soslaya u oculta lo positivo (2007a, p. 11).

Para concluir con la teoría en torno al racismo, Van Dijk ha identificado en sus diversos estudios del discurso racista distintas estrategias discursivas que sirven para encubrir el racismo:

a) Negación aparente: inicia con una cláusula positiva negando el prejuicio y le sigue una cláusula adversativa que expresa algo negativo acerca de las minorías (2000, p. 248).

b) Concesión aparente: es cuando reconocemos un error, pero insinuamos que el de los otros fue peor.

c) Empatía aparente: pretende hacernos hincapié en que las normas, las decisiones o las acciones negativas son en realidad beneficiosas para las víctimas (2000, p. 252). 
d) Excusa aparente: del tipo "perdón, pero...". Donde la primera cláusula busca cuidar la imagen o autoimagen y manejar las impresiones que los demás puedan tener sobre el fenómeno. Mientras que la parte introducida por la adversativa centra su atención en lo negativo de los otros. Trato de cuidar mi autoimagen degradando la del otro.

e) Transformación de lo contrario o revocación: busca ponernos a nosotros como víctimas y a ellos como discriminantes (2000, pp. 251-253).

f) Uso de demostrativos, corresponde en primer lugar del uso de los pronombres, los cuales sirven para indicar la pertenencia al grupo con el que se identifica y acentuar la distancia social, la desaprobación o el resentimiento con respecto de otros grupos: la oposición fundamental entre ellos y nosotros expresa contraste, oposición y conflicto social. Esto también se manifiesta mediante el uso de demostrativos como "esa gente". Además el autor señala que se usa ellos “en ocasiones en que sería más apropiado usar un nombre o una descripción".

g) Eufemismo: Van Dijk lo define como "un mecanismo destinado a guardar las apariencias" (2000, p. 250), pues verbalmente representa una cosa y en los hechos se refiere a otra.

h) Transferencia: se traspasa la responsabilidad a otro, por ejemplo: "No tengo nada en contra de los negros, pero mis clientes prefieren..." (2000, p. 250).

Hasta aquí, mi cometido ha sido visibilizar los hilos que se entretejen entre el texto literario, las identidades, particularmente la étnica y cómo estas construcciones están estrechamente relacionadas con el racismo, de manera tal que como estudiosos latinoamericanos de la literatura estamos llamados a trascender lo meramente estético y develar qué está haciendo el texto literario en relación con los discursos de la colonialidad: los apuntala y colabora en su supervivencia o los derruye y socava. Qué estamos haciendo nosotros, qué vamos a hacer. Esta disertación teórica es un esfuerzo por responder a la pregunta qué tiene que ver la literatura con el racismo (o cualquier otro de los sistemas de dominación), para ello he partido de la concepción del texto literario como práctica sociocultural que materializa, trabaja, produce, moldea, elabora y reelabora identidades, así como las ideologías (imaginarios, representaciones mentales y sistemas de valores) y las prácticas sociales ligadas a estas. De este modo, a través de tres grandes ejes: literatura como práctica social e ideológica, identidades y racismo, ofrezco herramientas teóricas para aquellos quieran leer un poco más allá de lo que tradicionalmente se nos propone. 


\section{Referencias}

Aínsa, Fernando. (1986). Identidad cultural de Iberoamérica en su narrativa. Madrid: Gredos.

Althusser, Louis. (2004). “Ideología y Aparatos Ideológicos de Estado”. Ideología: un mapa de la cuestión, pp. 115-155.

Amoretti Hurtado, María. (1992). Diccionario de términos asociados en teoría literaria. San José: EUCR.

Bajtín, Mijaíl. (2000). Yo también soy (fragmentos sobre el otro). Madrid: Taurus.

Bajtín, Mijaíl. (1989). Teoría y estética de la novela. Madrid: Taurus.

Bajtín, Mijaíl. (1982). Estética de la creación verbal. México: Siglo Veintiuno Editores.

Casaús Arzú, Marta Elena. (2010). El lenguaje de los ismos: algunos conceptos de la modernidad en América Latina. Ciudad de Guatemala: F \& G Editores.

Casaús Arzú. (2010). Guatemala: linaje y racismo. Antigua Guatemala: F \& G Editores.

Casaús Arzú. (1998). La metamorfosis del racismo en Guatemala. Ciudad de Guatemala: CHOLSAMAJ.

Cros, Edmond. (1997). El sujeto cultural. Sociocrítica y psicoanálisis. Buenos Aires: Ediciones Corregidor.

Cros, Edmond. (1986a) Literatura, ideología y sociedad. Madrid: Gredos.

Cros, Edmond. (1986b). Introducción a la Sociocrítica (Conferencia No. 1). Káñina 1: 69-76.

Cros, Edmond. (1986c). Introducción a la Sociocrítica (Conferencia No. 2). Káñina 1: 77-83.

Curcó, Carmen y Ezcurdia, Maite. (2009). "Identidad personal e identidad cultural: un panorama". En: Curcó, Carmen y Ezcurdia, Maite (Comps.). Discurso, identidad y cultura. México DF: UNAM: 7-30.

Duncan, Quince y Powell, Lorein. (1988). Teoría y práctica del racismo. San José: DEI.

Fanon, Frantz. (2009). Piel negra, máscaras blancas. Madrid: Akal.

García Martínez, Alfonso. (2004). La construcción sociocultural del racismo. Análisis y perspectivas. Madrid: Editorial DYKINSON.

Grosfoguel, Ramón. (2012). "El concepto de racismo en Michel Foucault y Franz Fanon: ¿teorizar desde la zona del ser o desde la zona del no ser?”. Tabula Rasa 16 (enero-junio): 79-102.

Gutiérrez Martínez, Daniel y Balselv Clausen, Helen (Coords.). (2008). Revisitar la etnicidad: miradas cruzadas en torno a la diversidad. México D.F.: Siglo XXI Editores-El Colegio Mexiquense-El Colegio de Sonora. 
Hall, Stuart. (2003). “Introducción: ¿quién necesita ‘identidad’?”. En: Stuart Hall y Paul Du Gay, (comps.). Cuestiones de identidad cultural. Madrid: Amorrortu Editores: 13-39.

Hering Torres, Max. (2007). “Raza: variables históricas”. Revista de Estudios Sociales 26: 16-27. Larraín Ibáñez, Jorge. (2003). "El concepto de identidad”. Revista FAMECOS 21: 30-42.

Larraín Ibáñez, Jorge. (1996). Modernidad, razón e identidad en América Latina. Santiago: Editorial Andrés Bello.

Mignolo, Walter. (2010). Desobediencia epistémica: retórica de la modernidad, lógica de la colonialidad y gramática de la descolonialidad. Buenos Aires: Ediciones del Signo.

Mignolo, Walter. (2007). La idea de América Latina. La herida colonial y la opción decolonial. Barcelona: Gedisa.

Morales, Gabriela. (2008). "Metamorfosis del paradigma del reconocimiento: Del racismo biológico al racismo cultural”. Universitas Revista de Filología, Derecho y Política 7: 7185.

Perceval, José María. (2013). El racismo y la xenofobia. Excluir al diferente. Madrid: Cátedra.

Quijano, Aníbal. (1992). “'Raza', ‘etnia’ y ‘nación’ en Mariátegui: cuestiones abiertas”. En: Forgues, Roland. ed. José Carlos Mariátegui y Europa: el otro aspecto del descubrimiento. Lima: Amauta, 1-14.

Quijano, Aníbal. (1999). “iQue tal raza!”. Ecuador Debate 48 (diciembre): 141-151.

Ramírez Caro, Jorge. (2004). La escenificación del escarnio en el Lazarillo de Tormes. Tesis. Universidad de Costa Rica: Sistema de Estudios de Posgrado. . (2000). "Lecturas intertextual e interdiscursiva en sociocrítica”. Letras 32: 137-161.

Restrepo, Eduardo. (2012). Intervenciones en teoría cultural. Cauca: Editorial Universidad del Cauca.

Restrepo, Eduardo. (2004). Teorías contemporáneas de la etnicidad: Stuart Hall y Michel Foucault. Popayán: Editorial Universidad del Cauca.

Restrepo, Eduardo y Rojas, Alex. (2009). Instrucción crítica al pensamiento descolonial. Bogotá: Universidad Javeriana.

Santos, Boaventura de Souza. (2010). Descolonizar el saber, reinventar el poder. Montevideo: Ediciones Trilce.

Santos, Boaventura de Souza. (1998). De la mano de Alicia: lo social y lo político en la posmodernidad. Bogotá: Siglo del Hombre Editores.

Taguieff, Pierre André. (2001). "El racismo”. Debate feminista (octubre): 3-14.

Van Dijk, Teun. (2010). “Análisis del discurso del racismo”. Crítica y Emancipación 3: 65-94. 
Van Dijk, Teun. (2007a). "Discurso racista". En: Juan José Igatua \& Carlos Múñiz. Eds. Medios de comunicación y sociedad. Salamanca: Ediciones Universidad de Salamanca: 9-16.

Van Dijk, Teun. Coord. (2007b). Racismo y discurso en América Latina. Barcelona: Gedisa.

Van Dijk, Teun. (2006). Ideología. Una aproximación multidisciplinaria. Barcelona: Gedisa.

Van Dijk, Teun. (2003). Dominación étnica y racismo discursivo en España y América Latina. Barcelona: Gedisa.

Van Dijk, Teun. (2003). Racismo y discurso de las elites. Barcelona: Gedisa.

Van Dijk, Teun. (2000). El discurso como interacción social. Barcelona: Gedisa.

Van Dijk, Teun. (1995). Racismo y análisis crítico de los medios. Barcelona: Paidós.

Van Dijk, Teun. (1988) “El discurso y la reproducción del racismo”. Lenguaje en contexto 1 (12), pp. 131-180.

Voloshinov, Valentin. (1992). El marxismo y la filosofía del lenguaje. Madrid: Alianza Editorial.

Wieviorka, Michel. (2009). El racismo: una introducción. Barcelona: Gedisa. 